University of Pennsylvania Carey Law School

Penn Law: Legal Scholarship Repository

Faculty Scholarship at Penn Law

6-13-2012

\title{
Innovation and Competition Policy: Statutory Supplement and Other Materials
}

Herbert J. Hovenkamp

University of Pennsylvania Carey Law School

Follow this and additional works at: https://scholarship.law.upenn.edu/faculty_scholarship

Part of the Antitrust and Trade Regulation Commons, Intellectual Property Law Commons, Law and Economics Commons, and the Legislation Commons

\section{Repository Citation}

Hovenkamp, Herbert J., "Innovation and Competition Policy: Statutory Supplement and Other Materials" (2012). Faculty Scholarship at Penn Law. 1908.

https://scholarship.law.upenn.edu/faculty_scholarship/1908

This Article is brought to you for free and open access by Penn Law: Legal Scholarship Repository. It has been accepted for inclusion in Faculty Scholarship at Penn Law by an authorized administrator of Penn Law: Legal Scholarship Repository. For more information, please contact PennlawIR@law.upenn.edu. 
Cases and Materials

Statutory and other Supplemental Materials

\section{INNOVATION AND COMPETITION POLICY Statutory Supplement and Other Materials}

\section{Herbert Hovenkamp}

This Supplement to Cases and Materials on Innovation and Competition Policy includes the following: (1) a statutory supplement containing relevant provisions of the antitrust laws, the Patent Act, the Copyright Act, and the DMCA: (2) an annotated table of contents. Other supplemental materials, including discussion of recent decisions or other developments will be added from time to time.

The casebook will be supplemented frequently as important new decisions or other developments occur. However, the author will attempt not to revise individual chapters during the course of the academic semester in order to avoid confusion in pagination or printing. Instead, supplemental materials will be merged into the main chapters during the summer and the winter break (late December or very early January) as needed.

CASES AND MATERIALS ON INNOVATION AND COMPETITION POLICY is intended for educational use. The book is free for all to use subject to an open source license agreement. It differs from IP/antitrust casebooks in that it considers numerous sources of competition policy in addition to antitrust, including those that emanate from the intellectual property laws themselves, and also related issues such as the relationship between market structure and innovation, the competitive consequences of regulatory rules governing technology competition such as net neutrality and interconnection, misuse, the first sale doctrine, and the Digital Millennium Copyright Act (DMCA). Chapters will be updated frequently. The author uses this casebook for a three-unit class in Innovation and Competition Policy taught at the University of Iowa College of Law and available to first year law students as an elective. The table of contents is as follows (click on chapter title to retrieve it):

Ch. 1: Competition Policy and the Scope of Intellectual Property Protection

Ch. 2 Complementary Products and Processes: The Law of Tying

Ch. 3 Harm to Competition or Innovation; Remedies

Ch. 4 Competition Policy and the Patent System

Ch. 5 Competition and Innovation in Copyright and the DMCA

Ch. 6 Restraints on Innovation

Ch. 7 Intellectual Property Misuse

Ch. 8 Innovation, Technology, and Anticompetitive Exclusion

Ch. 9 The Innovation Commons

Ch. 10; Post-Sale and Related Distribution Restraints Involving IP Rights

\section{Statutory Supplement and Other Materials}

\section{(C) 2011. Herbert Hovenkamp}

License Agreement: The Author hereby grants You a royalty-free, non-exclusive, license to (a) reproduce this Original Work in copies for any purpose including classroom use; (b) prepare derivative works based upon the Original Work; and (c) distribute electronic or printed copies of the Original Work and Derivative Works to others; provided that, acknowledgement of the original author be made on all distributions of the original or derivative works; and distribution shall be noncommercial and without charge, except that reasonable costs of printing and distribution may be passed on. No copyright is claimed in unedited government or other public domain documents. 
SELECTED PROVISIONS OF ANTITRUST LAWS, PATENT ACT, COPYRIGHT ACT, AND DMCA

\author{
SHERMAN ACT \\ 15 U.S.C. $\$ 1$
}

Every contract, combination in the form of trust or otherwise, or conspiracy, in restraint of trade or commerce among the several States, or with foreign nations, is declared to be illegal. Every person who shall make any contract or engage in any combination or conspiracy hereby declared to be illegal shall be deemed guilty of a felony, and, on conviction thereof, shall be punished by fine not exceeding $\$ 100,000,000$ if a corporation, or, if any other person, $\$ 1,000,000$, or by imprisonment not exceeding 10 years, or by both said punishments, in the discretion of the court.

15 U.S.C. 22

Every person who shall monopolize, or attempt to monopolize, or combine or conspire with any other person or persons, to monopolize any part of the trade or commerce among the several States, or with foreign nations, shall be deemed guilty of a felony, and, on conviction thereof, shall be punished by fine not exceeding $\$ 100,000,000$ if a corporation, or, if any other person, $\$ 1,000,000$, or by imprisonment not exceeding 10 years, or by both said punishments, in the discretion of the court.

\title{
CLAYTON ACT 15 U.S.C. $\$ 14$
}

It shall be unlawful for any person engaged in commerce, in the course of such commerce, to lease or make a sale or contract for sale of goods, wares, merchandise, machinery, supplies, or other commodities, whether patented or unpatented, for use, consumption, or resale within the United States or any Territory thereof or the District of Columbia or any insular possession or other place under the jurisdiction of the United States, or fix a price charged therefor, or discount from, or rebate upon, such price, on the condition, agreement, or understanding that the lessee or purchaser thereof shall not use or deal in the goods, wares, merchandise, machinery, supplies, or other commodities of a competitor or competitors of the lessor or seller, where the effect of such lease, sale, or contract for sale or such condition, agreement, or understanding may be to substantially lessen competition or tend to create a monopoly in any line of commerce.

\section{U.S.C. $\$ 15$}

... [A]ny person who shall be injured in his business or property by reason of anything forbidden in the antitrust laws may sue therefor in any district court of the United States in the district in which the defendant resides or is found or has an agent, without respect to the amount in controversy, and shall recover threefold the damages by him sustained, and the cost of suit, including a reasonable attorney's fee. 
Cases and Materials

Statutory and other Supplemental Materials

\section{U.S.C. $\$ 18$}

No person engaged in commerce or in any activity affecting commerce shall acquire, directly or indirectly, the whole or any part of the stock or other share capital and no person subject to the jurisdiction of the Federal Trade Commission shall acquire the whole or any part of the assets of another person engaged also in commerce or in any activity affecting commerce, where in any line of commerce or in any activity affecting commerce in any section of the country, the effect of such acquisition may be substantially to lessen competition, or to tend to create a monopoly.

\section{U.S.C. $§ 26$}

Any person, firm, corporation, or association shall be entitled to sue for and have injunctive relief, in any court of the United States having jurisdiction over the parties, against threatened loss or damage by a violation of the antitrust laws, including sections $13,14,18$, and 19 of this title, when and under the same conditions and principles as injunctive relief against threatened conduct that will cause loss or damage is granted by courts of equity, under the rules governing such proceedings....

\section{PATENT ACT}

\section{U.S.C. $\$ 100$}

When used in this title unless the context otherwise indicates--

(a) The term "invention" means invention or discovery.

(b) The term "process" means process, art or method, and includes a new use of a known process, machine, manufacture, composition of matter, or material.

(c) The terms "United States" and "this country" mean the United States of America, its territories and possessions.

(d) The word "patentee" includes not only the patentee to whom the patent was issued but also the successors in title to the patentee.

(e) The term "third-party requester" means a person requesting ex parte reexamination under section 302 or inter partes reexamination under section 311 who is not the patent owner.

\section{U.S.C. $\$ 101$ $\$ 101$ Inventions patentable}

Whoever invents or discovers any new and useful process, machine, manufacture, or composition of matter, or any new and useful improvement thereof, may obtain a patent therefor, subject to the conditions and requirements of this title.

35 U.S.C. \$102

$\S 102$. Conditions for patentability; novelty and loss of right to patent

A person shall be entitled to a patent unless-- 
(a) the invention was known or used by others in this country, or patented or described in a printed publication in this or a foreign country, before the invention thereof by the applicant for patent, or

(b) the invention was patented or described in a printed publication in this or a foreign country or in public use or on sale in this country, more than one year prior to the date of the application for patent in the United States, or

(c) he has abandoned the invention, or

(d) the invention was first patented or caused to be patented, or was the subject of an inventor's certificate, by the applicant or his legal representatives or assigns in a foreign country prior to the date of the application for patent in this country on an application for patent or inventor's certificate filed more than twelve months before the filing of the application in the United States, or

(e) the invention was described in (1) an application for patent, published under section 122(b), by another filed in the United States before the invention by the applicant for patent or (2) a patent granted on an application for patent by another filed in the United States before the invention by the applicant for patent, except that an international application filed under the treaty defined in section 351(a) shall have the effects for the purposes of this subsection of an application filed in the United States only if the international application designated the United States and was published under Article 21(2) of such treaty in the English language; or (f) he did not himself invent the subject matter sought to be patented, or (g)(1) during the course of an interference conducted under section 135 or section 291, another inventor involved therein establishes, to the extent permitted in section 104, that before such person's invention thereof the invention was made by such other inventor and not abandoned, suppressed, or concealed, or (2) before such person's invention thereof, the invention was made in this country by another inventor who had not abandoned, suppressed, or concealed it. In determining priority of invention under this subsection, there shall be considered not only the respective dates of conception and reduction to practice of the invention, but also the reasonable diligence of one who was first to conceive and last to reduce to practice, from a time prior to conception by the other.

35 U.S.C. $\$ 103$

\section{$\S 103$. Conditions for patentability; non-obvious subject matter}

(a) A patent may not be obtained though the invention is not identically disclosed or described as set forth in section 102 of this title, if the differences between the subject matter sought to be patented and the prior art are such that the subject matter as a whole would have been obvious at the time the invention was made to a person having ordinary skill in the art to which said subject matter pertains. Patentability shall not be negatived by the manner in which the invention was made.

(b) (1) Notwithstanding subsection (a), and upon timely election by the applicant for patent to proceed under this subsection, a biotechnological process using or resulting in a composition of matter that is novel under section 102 and nonobvious under subsection (a) of this section shall be considered nonobvious if- 
Cases and Materials

Statutory and other Supplemental Materials

(A) claims to the process and the composition of matter are contained in either the same application for patent or in separate applications having the same effective filing date; and

(B) the composition of matter, and the process at the time it was invented, were owned by the same person or subject to an obligation of assignment to the same person.

(2) A patent issued on a process under paragraph (1)--

(A) shall also contain the claims to the composition of matter used in or made by that process, or

(B) shall, if such composition of matter is claimed in another patent, be set to expire on the same date as such other patent, notwithstanding section 154.

(3) For purposes of paragraph (1), the term "biotechnological process" means--

(A) a process of genetically altering or otherwise inducing a single- or multi-celled organism to--

(i) express an exogenous nucleotide sequence,

(ii) inhibit, eliminate, augment, or alter expression of an endogenous nucleotide sequence, or

(iii) express a specific physiological characteristic not naturally associated with said organism;

(B) cell fusion procedures yielding a cell line that expresses a specific protein, such as a monoclonal antibody; and

(C) a method of using a product produced by a process defined by subparagraph (A) or

(B), or a combination of subparagraphs (A) and (B).

(c) (1) Subject matter developed by another person, which qualifies as prior art only under one or more of subsections (e), (f), and (g) of section 102 of this title, shall not preclude patentability under this section where the subject matter and the claimed invention were, at the time the claimed invention was made, owned by the same person or subject to an obligation of assignment to the same person.

(2) For purposes of this subsection, subject matter developed by another person and a claimed invention shall be deemed to have been owned by the same person or subject to an obligation of assignment to the same person if--

(A) the claimed invention was made by or on behalf of parties to a joint research agreement that was in effect on or before the date the claimed invention was made;

(B) the claimed invention was made as a result of activities undertaken within the scope of the joint research agreement; and

(C) the application for patent for the claimed invention discloses or is amended to disclose the names of the parties to the joint research agreement.

(3) For purposes of paragraph (2), the term "joint research agreement" means a written contract, grant, or cooperative agreement entered into by two or more persons or entities for the performance of experimental, developmental, or research work in the field of the claimed invention.

\section{U.S.C. $\$ 112$ \\ $\S$ 112. Specification}

The specification shall contain a written description of the invention, and of the manner and process of making and using it, in such full, clear, concise, and exact terms as to enable any 
Cases and Materials

Statutory and other Supplemental Materials

person skilled in the art to which it pertains, or with which it is most nearly connected, to make and use the same, and shall set forth the best mode contemplated by the inventor of carrying out his invention.

The specification shall conclude with one or more claims particularly pointing out and distinctly claiming the subject matter which the applicant regards as his invention.

A claim may be written in independent or, if the nature of the case admits, in dependent or multiple dependent form.

Subject to the following paragraph, a claim in dependent form shall contain a reference to a claim previously set forth and then specify a further limitation of the subject matter claimed. A claim in dependent form shall be construed to incorporate by reference all the limitations of the claim to which it refers.

A claim in multiple dependent form shall contain a reference, in the alternative only, to more than one claim previously set forth and then specify a further limitation of the subject matter claimed. A multiple dependent claim shall not serve as a basis for any other multiple dependent claim. A multiple dependent claim shall be construed to incorporate by reference all the limitations of the particular claim in relation to which it is being considered.

An element in a claim for a combination may be expressed as a means or step for performing a specified function without the recital of structure, material, or acts in support thereof, and such claim shall be construed to cover the corresponding structure, material, or acts described in the specification and equivalents thereof.

35 U.S.C. $\$ 171$

\section{$\S$ 171. Patents for designs}

Whoever invents any new, original and ornamental design for an article of manufacture may obtain a patent therefor, subject to the conditions and requirements of this title.

The provisions of this title relating to patents for inventions shall apply to patents for designs, except as otherwise provided.

\section{U.S.C. $\$ 211$}

\section{\$ 211. Relationship to antitrust laws}

Nothing in this chapter shall be deemed to convey to any person immunity from civil or criminal liability, or to create any defenses to actions, under any antitrust law.

\section{U.S.C. $\$ 261$}

\section{§ 261. Ownership; assignment}

Subject to the provisions of this title, patents shall have the attributes of personal property. Applications for patent, patents, or any interest therein, shall be assignable in law by an instrument in writing. The applicant, patentee, or his assigns or legal representatives may in like 
Cases and Materials

\section{Statutory and other Supplemental Materials}

manner grant and convey an exclusive right under his application for patent, or patents, to the whole or any specified part of the United States.

A certificate of acknowledgment under the hand and official seal of a person authorized to administer oaths within the United States, or, in a foreign country, of a diplomatic or consular officer of the United States or an officer authorized to administer oaths whose authority is proved by a certificate of a diplomatic or consular officer of the United States, or apostille of an official designated by a foreign country which, by treaty or convention, accords like effect to apostilles of designated officials in the United States, shall be prima facie evidence of the execution of an assignment, grant or conveyance of a patent or application for patent.

An assignment, grant or conveyance shall be void as against any subsequent purchaser or mortgagee for a valuable consideration, without notice, unless it is recorded in the Patent and Trademark Office within three months from its date or prior to the date of such subsequent purchase or mortgage.

\section{U.S.C. $\$ 271$}

\section{\$271. Infringement of patent}

(a) Except as otherwise provided in this title, whoever without authority makes, uses, offers to sell, or sells any patented invention, within the United States or imports into the United States any patented invention during the term of the patent therefor, infringes the patent.

(b) Whoever actively induces infringement of a patent shall be liable as an infringer.

(c) Whoever offers to sell or sells within the United States or imports into the United States a component of a patented machine, manufacture, combination or composition, or a material or apparatus for use in practicing a patented process, constituting a material part of the invention, knowing the same to be especially made or especially adapted for use in an infringement of such patent, and not a staple article or commodity of commerce suitable for substantial noninfringing use, shall be liable as a contributory infringer.

(d) No patent owner otherwise entitled to relief for infringement or contributory infringement of a patent shall be denied relief or deemed guilty of misuse or illegal extension of the patent right by reason of his having done one or more of the following: (1) derived revenue from acts which if performed by another without his consent would constitute contributory infringement of the patent; (2) licensed or authorized another to perform acts which if performed without his consent would constitute contributory infringement of the patent; (3) sought to enforce his patent rights against infringement or contributory infringement; (4) refused to license or use any rights to the patent; or (5) conditioned the license of any rights to the patent or the sale of the patented product on the acquisition of a license to rights in another patent or purchase of a separate product, unless, in view of the circumstances, the patent owner has market power in the relevant market for the patent or patented product on which the license or sale is conditioned. 
(e) (1) It shall not be an act of infringement to make, use, offer to sell, or sell within the United States or import into the United States a patented invention (other than a new animal drug or veterinary biological product (as those terms are used in the Federal Food, Drug, and Cosmetic Act and the Act of March 4, 1913) which is primarily manufactured using recombinant DNA, recombinant RNA, hybridoma technology, or other processes involving site specific genetic manipulation techniques) solely for uses reasonably related to the development and submission of information under a Federal law which regulates the manufacture, use, or sale of drugs or veterinary biological products.

(2) It shall be an act of infringement to submit-

(A) an application under section 505(j) of the Federal Food, Drug, and Cosmetic Act or described in section 505(b)(2) of such Act for a drug claimed in a patent or the use of which is claimed in a patent,

(B) an application under section 512 of such Act or under the Act of March 4, 1913

(21 U.S.C. 151-158) for a drug or veterinary biological product which is not primarily manufactured using recombinant DNA, recombinant RNA, hybridoma technology, or other processes involving site specific genetic manipulation techniques and which is claimed in a patent or the use of which is claimed in a patent, or (C)(i) with respect to a patent that is identified in the list of patents described in section 351(1)(3) of the Public Health Service Act (including as provided under section 351(1)(7) of such Act), an application seeking approval of a biological product, or

(ii) if the applicant for the application fails to provide the application and information required under section 351(1)(2)(A) of such Act, an application seeking approval of a biological product for a patent that could be identified pursuant to section 351(1)(3)(A)(i) of such Act, if the purpose of such submission is to obtain approval under such Act to engage in the commercial manufacture, use, or sale of a drug, veterinary biological product, or biological product claimed in a patent or the use of which is claimed in a patent before the expiration of such patent.

(3) In any action for patent infringement brought under this section, no injunctive or other relief may be granted which would prohibit the making, using, offering to sell, or selling within the United States or importing into the United States of a patented invention under paragraph (1).

(4) For an act of infringement described in paragraph (2)--

(A) the court shall order the effective date of any approval of the drug or veterinary biological product involved in the infringement to be a date which is not earlier than the date of the expiration of the patent which has been infringed,

(B) injunctive relief may be granted against an infringer to prevent the commercial manufacture, use, offer to sell, or sale within the United States or importation into the United States of an approved drug, veterinary biological product, or biological product,

(C) damages or other monetary relief may be awarded against an infringer only if there has been commercial manufacture, use, offer to sell, or sale within the United States or importation into the United States of an approved drug, veterinary biological product, or biological product, and 
(D) the court shall order a permanent injunction prohibiting any infringement of the patent by the biological product involved in the infringement until a date which is not earlier than the date of the expiration of the patent that has been infringed under paragraph $(2)(\mathrm{C})$, provided the patent is the subject of a final court decision, as defined in section 351(k)(6) of the Public Health Service Act, in an action for infringement of the patent under section 351(1)(6) of such Act, and the biological product has not yet been approved because of section $351(\mathrm{k})(7)$ of such Act. The remedies prescribed by subparagraphs (A), (B), (C), and (D) are the only remedies which may be granted by a court for an act of infringement described in paragraph (2), except that a court may award attorney fees under section 285.

(5) Where a person has filed an application described in paragraph (2) that includes a certification under subsection (b)(2)(A)(iv) or (j)(2)(A)(vii)(IV) of section 505 of the Federal Food, Drug, and Cosmetic Act (21 U.S.C. 355), and neither the owner of the patent that is the subject of the certification nor the holder of the approved application under subsection (b) of such section for the drug that is claimed by the patent or a use of which is claimed by the patent brought an action for infringement of such patent before the expiration of 45 days after the date on which the notice given under subsection (b)(3) or $(\mathrm{j})(2)(B)$ of such section was received, the courts of the United States shall, to the extent consistent with the Constitution, have subject matter jurisdiction in any action brought by such person under section 2201 of title 28 for a declaratory judgment that such patent is invalid or not infringed.

(6)(A) Subparagraph (B) Applies, in lieu of paragraph (4), in the case of a patent-(i) that is identified, as applicable, in the list of patents described in section 351(1)(4) of the Public Health Service Act or the lists of patents described in section 351(1)(5)(B) of such Act with respect to a biological product; and (ii) for which an action for infringement of the patent with respect to the biological product--

(I) was brought after the expiration of the 30-day period described in subparagraph (A) or (B), as applicable, of section 351(1)(6) of such Act; or (II) was brought before the expiration of the 30-day period described in subclause (I), but which was dismissed without prejudice or was not prosecuted to judgment in good faith.

(B) In an action for infringement of a patent described in subparagraph (A), the sole and exclusive remedy that may be granted by a court, upon a finding that the making, using, offering to sell, selling, or importation into the United States of the biological product that is the subject of the action infringed the patent, shall be a reasonable royalty.

(C) The owner of a patent that should have been included in the list described in section 351(1)(3)(A) of the Public Health Service Act, including as provided under section 351(1)(7) of such Act for a biological product, but was not timely included in such list, may not bring an action under this section for infringement of the patent with respect to the biological product.

(f)(1) Whoever without authority supplies or causes to be supplied in or from the United States all or a substantial portion of the components of a patented invention, where such components are uncombined in whole or in part, in such manner as to actively induce the 
Cases and Materials

Statutory and other Supplemental Materials

combination of such components outside of the United States in a manner that would infringe the patent if such combination occurred within the United States, shall be liable as an infringer.

(2) Whoever without authority supplies or causes to be supplied in or from the United States any component of a patented invention that is especially made or especially adapted for use in the invention and not a staple article or commodity of commerce suitable for substantial noninfringing use, where such component is uncombined in whole or in part, knowing that such component is so made or adapted and intending that such component will be combined outside of the United States in a manner that would infringe the patent if such combination occurred within the United States, shall be liable as an infringer.

(g) Whoever without authority imports into the United States or offers to sell, sells, or uses within the United States a product which is made by a process patented in the United States shall be liable as an infringer, if the importation, offer to sell, sale, or use of the product occurs during the term of such process patent. In an action for infringement of a process patent, no remedy may be granted for infringement on account of the noncommercial use or retail sale of a product unless there is no adequate remedy under this title for infringement on account of the importation or other use, offer to sell, or sale of that product. A product which is made by a patented process will, for purposes of this title, not be considered to be so made after--

(1) it is materially changed by subsequent processes; or

(2) it becomes a trivial and nonessential component of another product.

(h) As used in this section, the term "whoever" includes any State, any instrumentality of

State, and any officer or employee of a State or instrumentality of a State acting in his official capacity. Any State, and any such instrumentality, officer, or employee, shall be subject to the provisions of this title in the same manner and to the same extent as any nongovernmental entity.

(i) As used in this section, an "offer for sale" or an "offer to sell" by a person other than the patentee, or any designee of the patentee, is that in which the sale will occur before the expiration of the term of the patent.

\section{U.S.C. $\$ 282$}

\section{$\S 282$. Presumption of validity; defenses}

A patent shall be presumed valid. Each claim of a patent (whether in independent, dependent, or multiple dependent form) shall be presumed valid independently of the validity of other claims; dependent or multiple dependent claims shall be presumed valid even though dependent upon an invalid claim. Notwithstanding the preceding sentence, if a claim to a composition of matter is held invalid and that claim was the basis of a determination of nonobviousness under section 103(b)(1), the process shall no longer be considered nonobvious solely on the basis of section 103(b)(1). The burden of establishing invalidity of a patent or any claim thereof shall rest on the party asserting such invalidity.

The following shall be defenses in any action involving the validity or infringement of a patent and shall be pleaded:

(1) Noninfringement, absence of liability for infringement or unenforceability, 
Cases and Materials

Statutory and other Supplemental Materials

(2) Invalidity of the patent or any claim in suit on any ground specified in part II of this title as a condition for patentability,

(3) Invalidity of the patent or any claim in suit for failure to comply with--

(A) any requirement of section 112, except that the failure to disclose the best mode shall not be a basis on which any claim of a patent may be canceled or held invalid or

otherwise unenforceable; or

(B) any requirement of section 251 .

(4) Any other fact or act made a defense by this title.

In actions involving the validity or infringement of a patent the party asserting invalidity or noninfringement shall give notice in the pleadings or otherwise in writing to the adverse party at least thirty days before the trial, of the country, number, date, and name of the patentee of any patent, the title, date, and page numbers of any publication to be relied upon as anticipation of the patent in suit or, except in actions in the United States Court of Federal Claims, as showing the state of the art, and the name and address of any person who may be relied upon as the prior inventor or as having prior knowledge of or as having previously used or offered for sale the invention of the patent in suit. In the absence of such notice proof of the said matters may not be made at the trial except on such terms as the court requires. Invalidity of the extension of a patent term or any portion thereof under section 154(b) or 156 of this title because of the material failure--

(1) by the applicant for the extension, or

(2) by the Director,

to comply with the requirements of such section shall be a defense in any action involving the infringement of a patent during the period of the extension of its term and shall be pleaded. A due diligence determination under section $156(\mathrm{~d})(2)$ is not subject to review in such an action.

35 U.S.C. $\$ 283$

\section{$\S 283$. Injunction}

The several courts having jurisdiction of cases under this title may grant injunctions in accordance with the principles of equity to prevent the violation of any right secured by patent, on such terms as the court deems reasonable.

35 U.S.C. $\$ 284$

\section{$\S$ 284. Damages}

Upon finding for the claimant the court shall award the claimant damages adequate to compensate for the infringement, but in no event less than a reasonable royalty for the use made of the invention by the infringer, together with interest and costs as fixed by the court. When the damages are not found by a jury, the court shall assess them. In either event the court may increase the damages up to three times the amount found or assessed. Increased damages under this paragraph shall not apply to provisional rights under section 154(d) of this title. The court may receive expert testimony as an aid to the determination of damages or of what royalty would be reasonable under the circumstances. 
Cases and Materials

Statutory and other Supplemental Materials

\author{
COPYRIGHT ACT \\ 17 U.S.C. $\$ 1101-103,106-107,301-302,502,504$ \\ 17 U.S.C. $\$ 101$ \\ $\S$ 101. Definitions
}

Except as otherwise provided in this title, as used in this title, the following terms and their variant forms mean the following:

An "anonymous work" is a work on the copies or phonorecords of which no natural person is identified as author.

An "architectural work" is the design of a building as embodied in any tangible medium of expression, including a building, architectural plans, or drawings. The work includes the overall form as well as the arrangement and composition of spaces and elements in the design, but does not include individual standard features.

"Audiovisual works" are works that consist of a series of related images which are intrinsically intended to be shown by the use of machines, or devices such as projectors, viewers, or electronic equipment, together with accompanying sounds, if any, regardless of the nature of the material objects, such as films or tapes, in which the works are embodied.

The "Berne Convention" is the Convention for the Protection of Literary and Artistic Works, signed at Berne, Switzerland, on September 9, 1886, and all acts, protocols, and revisions thereto.

The "best edition" of a work is the edition, published in the United States at any time before the date of deposit, that the Library of Congress determines to be most suitable for its purposes.

A person's "children" are that person's immediate offspring, whether legitimate or not, and any children legally adopted by that person.

A "collective work" is a work, such as a periodical issue, anthology, or encyclopedia, in which a number of contributions, constituting separate and independent works in themselves, are assembled into a collective whole.

A "compilation" is a work formed by the collection and assembling of preexisting materials or of data that are selected, coordinated, or arranged in such a way that the resulting work as a whole constitutes an original work of authorship. The term "compilation" includes collective works.

A "computer program" is a set of statements or instructions to be used directly or indirectly in a computer in order to bring about a certain result.

"Copies" are material objects, other than phonorecords, in which a work is fixed by any method now known or later developed, and from which the work can be perceived, reproduced, or 
Cases and Materials

\section{Statutory and other Supplemental Materials}

otherwise communicated, either directly or with the aid of a machine or device. The term "copies" includes the material object, other than a phonorecord, in which the work is first fixed. "Copyright owner", with respect to any one of the exclusive rights comprised in a copyright, refers to the owner of that particular right.

A “Copyright Royalty Judge" is a Copyright Royalty Judge appointed under section 802 of this title, and includes any individual serving as an interim Copyright Royalty Judge under such section.

A work is "created" when it is fixed in a copy or phonorecord for the first time; where a work is prepared over a period of time, the portion of it that has been fixed at any particular time constitutes the work as of that time, and where the work has been prepared in different versions, each version constitutes a separate work.

A "derivative work" is a work based upon one or more preexisting works, such as a translation, musical arrangement, dramatization, fictionalization, motion picture version, sound recording, art reproduction, abridgment, condensation, or any other form in which a work may be recast, transformed, or adapted. A work consisting of editorial revisions, annotations, elaborations, or other modifications which, as a whole, represent an original work of authorship, is a "derivative work".

A "device", "machine", or "process" is one now known or later developed.

A "digital transmission" is a transmission in whole or in part in a digital or other non-analog format.

To "display" a work means to show a copy of it, either directly or by means of a film, slide, television image, or any other device or process or, in the case of a motion picture or other audiovisual work, to show individual images nonsequentially.

An "establishment" is a store, shop, or any similar place of business open to the general public for the primary purpose of selling goods or services in which the majority of the gross square feet of space that is nonresidential is used for that purpose, and in which nondramatic musical works are performed publicly.

The term "financial gain" includes receipt, or expectation of receipt, of anything of value, including the receipt of other copyrighted works.

A work is "fixed" in a tangible medium of expression when its embodiment in a copy or phonorecord, by or under the authority of the author, is sufficiently permanent or stable to permit it to be perceived, reproduced, or otherwise communicated for a period of more than transitory duration. A work consisting of sounds, images, or both, that are being transmitted, is "fixed" for purposes of this title if a fixation of the work is being made simultaneously with its transmission. 
Cases and Materials

\section{Statutory and other Supplemental Materials}

A "food service or drinking establishment" is a restaurant, inn, bar, tavern, or any other similar place of business in which the public or patrons assemble for the primary purpose of being served food or drink, in which the majority of the gross square feet of space that is nonresidential is used for that purpose, and in which nondramatic musical works are performed publicly.

The "Geneva Phonograms Convention" is the Convention for the Protection of Producers of Phonograms Against Unauthorized Duplication of Their Phonograms, concluded at Geneva, Switzerland, on October 29, 1971.

The "gross square feet of space" of an establishment means the entire interior space of that establishment, and any adjoining outdoor space used to serve patrons, whether on a seasonal basis or otherwise.

The terms "including" and "such as" are illustrative and not limitative.

An "international agreement" is--

(1) the Universal Copyright Convention;

(2) the Geneva Phonograms Convention;

(3) the Berne Convention;

(4) the WTO Agreement;

(5) the WIPO Copyright Treaty;

(6) the WIPO Performances and Phonograms Treaty; and

(7) any other copyright treaty to which the United States is a party.

A "joint work" is a work prepared by two or more authors with the intention that their contributions be merged into inseparable or interdependent parts of a unitary whole.

"Literary works" are works, other than audiovisual works, expressed in words, numbers, or other verbal or numerical symbols or indicia, regardless of the nature of the material objects, such as books, periodicals, manuscripts, phonorecords, film, tapes, disks, or cards, in which they are embodied.

The term "motion picture exhibition facility" means a movie theater, screening room, or other venue that is being used primarily for the exhibition of a copyrighted motion picture, if such exhibition is open to the public or is made to an assembled group of viewers outside of a normal circle of a family and its social acquaintances.

"Motion pictures" are audiovisual works consisting of a series of related images which, when shown in succession, impart an impression of motion, together with accompanying sounds, if any.

To "perform" a work means to recite, render, play, dance, or act it, either directly or by means of any device or process or, in the case of a motion picture or other audiovisual work, to show its images in any sequence or to make the sounds accompanying it audible. 
A "performing rights society" is an association, corporation, or other entity that licenses the public performance of nondramatic musical works on behalf of copyright owners of such works, such as the American Society of Composers, Authors and Publishers (ASCAP), Broadcast Music, Inc. (BMI), and SESAC, Inc.

"Phonorecords" are material objects in which sounds, other than those accompanying a motion picture or other audiovisual work, are fixed by any method now known or later developed, and from which the sounds can be perceived, reproduced, or otherwise communicated, either directly or with the aid of a machine or device. The term "phonorecords" includes the material object in which the sounds are first fixed.

"Pictorial, graphic, and sculptural works" include two-dimensional and three-dimensional works of fine, graphic, and applied art, photographs, prints and art reproductions, maps, globes, charts, diagrams, models, and technical drawings, including architectural plans. Such works shall include works of artistic craftsmanship insofar as their form but not their mechanical or utilitarian aspects are concerned; the design of a useful article, as defined in this section, shall be considered a pictorial, graphic, or sculptural work only if, and only to the extent that, such design incorporates pictorial, graphic, or sculptural features that can be identified separately from, and are capable of existing independently of, the utilitarian aspects of the article.

For purposes of section 513, a "proprietor" is an individual, corporation, partnership, or other entity, as the case may be, that owns an establishment or a food service or drinking establishment, except that no owner or operator of a radio or television station licensed by the Federal Communications Commission, cable system or satellite carrier, cable or satellite carrier service or programmer, provider of online services or network access or the operator of facilities therefor, telecommunications company, or any other such audio or audiovisual service or programmer now known or as may be developed in the future, commercial subscription music service, or owner or operator of any other transmission service, shall under any circumstances be deemed to be a proprietor.

A "pseudonymous work" is a work on the copies or phonorecords of which the author is identified under a fictitious name.

"Publication" is the distribution of copies or phonorecords of a work to the public by sale or other transfer of ownership, or by rental, lease, or lending. The offering to distribute copies or phonorecords to a group of persons for purposes of further distribution, public performance, or public display, constitutes publication. A public performance or display of a work does not of itself constitute publication.

To perform or display a work "publicly" means--

(1) to perform or display it at a place open to the public or at any place where a substantial number of persons outside of a normal circle of a family and its social acquaintances is gathered; or

(2) to transmit or otherwise communicate a performance or display of the work to a place specified by clause (1) or to the public, by means of any device or process, whether the 
Cases and Materials

Statutory and other Supplemental Materials

members of the public capable of receiving the performance or display receive it in the same place or in separate places and at the same time or at different times.

"Registration", for purposes of sections 205(c)(2), 405, 406, 410(d), 411, 412, and 506(e), means a registration of a claim in the original or the renewed and extended term of copyright.

"Sound recordings" are works that result from the fixation of a series of musical, spoken, or other sounds, but not including the sounds accompanying a motion picture or other audiovisual work, regardless of the nature of the material objects, such as disks, tapes, or other phonorecords, in which they are embodied.

"State" includes the District of Columbia and the Commonwealth of Puerto Rico, and any territories to which this title is made applicable by an Act of Congress.

A "transfer of copyright ownership" is an assignment, mortgage, exclusive license, or any other conveyance, alienation, or hypothecation of a copyright or of any of the exclusive rights comprised in a copyright, whether or not it is limited in time or place of effect, but not including a nonexclusive license.

A "transmission program" is a body of material that, as an aggregate, has been produced for the sole purpose of transmission to the public in sequence and as a unit.

To "transmit" a performance or display is to communicate it by any device or process whereby images or sounds are received beyond the place from which they are sent.

A "treaty party" is a country or intergovernmental organization other than the United States that is a party to an international agreement.

The "United States", when used in a geographical sense, comprises the several States, the District of Columbia and the Commonwealth of Puerto Rico, and the organized territories under the jurisdiction of the United States Government.

For purposes of section 411, a work is a "United States work" only if--

(1) in the case of a published work, the work is first published--

(A) in the United States;

(B) simultaneously in the United States and another treaty party or parties, whose law grants a term of copyright protection that is the same as or longer than the term provided in the United States;

(C) simultaneously in the United States and a foreign nation that is not a treaty party; or

(D) in a foreign nation that is not a treaty party, and all of the authors of the work are nationals, domiciliaries, or habitual residents of, or in the case of an audiovisual work legal entities with headquarters in, the United States;

(2) in the case of an unpublished work, all the authors of the work are nationals, domiciliaries, or habitual residents of the United States, or, in the case of an unpublished 
Cases and Materials

\section{Statutory and other Supplemental Materials}

audiovisual work, all the authors are legal entities with headquarters in the United States; or

(3) in the case of a pictorial, graphic, or sculptural work incorporated in a building or structure, the building or structure is located in the United States.

A "useful article" is an article having an intrinsic utilitarian function that is not merely to portray the appearance of the article or to convey information. An article that is normally a part of a useful article is considered a "useful article".

The author's "widow" or "widower" is the author's surviving spouse under the law of the author's domicile at the time of his or her death, whether or not the spouse has later remarried.

The "WIPO Copyright Treaty" is the WIPO Copyright Treaty concluded at Geneva, Switzerland, on December 20, 1996.

The "WIPO Performances and Phonograms Treaty" is the WIPO Performances and Phonograms Treaty concluded at Geneva, Switzerland, on December 20, 1996.

A "work of visual art" is--

(1) a painting, drawing, print, or sculpture, existing in a single copy, in a limited edition of 200 copies or fewer that are signed and consecutively numbered by the author, or, in the case of a sculpture, in multiple cast, carved, or fabricated sculptures of 200 or fewer that are consecutively numbered by the author and bear the signature or other identifying mark of the author; or

(2) a still photographic image produced for exhibition purposes only, existing in a single copy that is signed by the author, or in a limited edition of 200 copies or fewer that are signed and consecutively numbered by the author.

A work of visual art does not include--

(A)(i) any poster, map, globe, chart, technical drawing, diagram, model, applied art, motion picture or other audiovisual work, book, magazine, newspaper, periodical, data base, electronic information service, electronic publication, or similar publication;

(ii) any merchandising item or advertising, promotional, descriptive, covering, or packaging material or container;

(iii) any portion or part of any item described in clause (i) or (ii);

(B) any work made for hire; or

(C) any work not subject to copyright protection under this title.

A "work of the United States Government" is a work prepared by an officer or employee of the United States Government as part of that person's official duties.

A "work made for hire" is--

(1) a work prepared by an employee within the scope of his or her employment; or

(2) a work specially ordered or commissioned for use as a contribution to a collective

work, as a part of a motion picture or other audiovisual work, as a translation, as a 
Cases and Materials

\section{Statutory and other Supplemental Materials}

supplementary work, as a compilation, as an instructional text, as a test, as answer material for a test, or as an atlas, if the parties expressly agree in a written instrument signed by them that the work shall be considered a work made for hire. For the purpose of the foregoing sentence, a "supplementary work" is a work prepared for publication as a secondary adjunct to a work by another author for the purpose of introducing, concluding, illustrating, explaining, revising, commenting upon, or assisting in the use of the other work, such as forewords, afterwords, pictorial illustrations, maps, charts, tables, editorial notes, musical arrangements, answer material for tests, bibliographies, appendixes, and indexes, and an "instructional text" is a literary, pictorial, or graphic work prepared for publication and with the purpose of use in systematic instructional activities.

In determining whether any work is eligible to be considered a work made for hire under paragraph (2), neither the amendment contained in section 1011(d) of the Intellectual Property and Communications Omnibus Reform Act of 1999, as enacted by section 1000(a)(9) of Public Law 106-113, nor the deletion of the words added by that amendment--

(A) shall be considered or otherwise given any legal significance, or

(B) shall be interpreted to indicate congressional approval or disapproval of, or acquiescence in, any judicial determination, by the courts or the Copyright Office. Paragraph (2) shall be interpreted as if both section 2(a)(1) of the Work Made For Hire and Copyright Corrections Act of 2000 and section 1011(d) of the Intellectual Property and Communications Omnibus Reform Act of 1999, as enacted by section 1000(a)(9) of Public Law 106-113, were never enacted, and without regard to any inaction or awareness by the Congress at any time of any judicial determinations.

The terms "WTO Agreement" and "WTO member country" have the meanings given those terms in paragraphs (9) and (10), respectively, of section 2 of the Uruguay Round Agreements Act.

\section{U.S.C. $\$ 102$}

\section{$\S 102$. Subject matter of copyright: In general}

(a) Copyright protection subsists, in accordance with this title, in original works of authorship fixed in any tangible medium of expression, now known or later developed, from which they can be perceived, reproduced, or otherwise communicated, either directly or with the aid of a machine or device. Works of authorship include the following categories:

(1) literary works;

(2) musical works, including any accompanying words;

(3) dramatic works, including any accompanying music;

(4) pantomimes and choreographic works;

(5) pictorial, graphic, and sculptural works;

(6) motion pictures and other audiovisual works;

(7) sound recordings; and

(8) architectural works. 
Cases and Materials

\section{Statutory and other Supplemental Materials}

(b) In no case does copyright protection for an original work of authorship extend to any idea, procedure, process, system, method of operation, concept, principle, or discovery, regardless of the form in which it is described, explained, illustrated, or embodied in such work.

17 U.S.C. $\$ 103$

\section{$\S 103$. Subject matter of copyright: Compilations and derivative works}

(a) The subject matter of copyright as specified by section 102 includes compilations and derivative works, but protection for a work employing preexisting material in which copyright subsists does not extend to any part of the work in which such material has been used unlawfully.

(b) The copyright in a compilation or derivative work extends only to the material contributed by the author of such work, as distinguished from the preexisting material employed in the work, and does not imply any exclusive right in the preexisting material. The copyright in such work is independent of, and does not affect or enlarge the scope, duration, ownership, or subsistence of, any copyright protection in the preexisting material.

(c)

17 U.S.C. $\$ 106$

\section{$\S 106$. Exclusive rights in copyrighted works}

Subject to sections 107 through 122, the owner of copyright under this title has the exclusive rights to do and to authorize any of the following:

(1) to reproduce the copyrighted work in copies or phonorecords;

(2) to prepare derivative works based upon the copyrighted work;

(3) to distribute copies or phonorecords of the copyrighted work to the public by sale or other transfer of ownership, or by rental, lease, or lending;

(4) in the case of literary, musical, dramatic, and choreographic works, pantomimes, and motion pictures and other audiovisual works, to perform the copyrighted work publicly;

(5) in the case of literary, musical, dramatic, and choreographic works, pantomimes, and pictorial, graphic, or sculptural works, including the individual images of a motion picture or other audiovisual work, to display the copyrighted work publicly; and

(6) in the case of sound recordings, to perform the copyrighted work publicly by means of a digital audio transmission.

17 U.S.C. $\$ 107$

\section{$\S 107$. Limitations on exclusive rights: Fair use}

Notwithstanding the provisions of sections 106 and 106A, the fair use of a copyrighted work, including such use by reproduction in copies or phonorecords or by any other means specified by that section, for purposes such as criticism, comment, news reporting, teaching (including multiple copies for classroom use), scholarship, or research, is not an infringement of copyright. In determining whether the use made of a work in any particular case is a fair use the factors to be considered shall include--

(1) the purpose and character of the use, including whether such use is of a commercial nature or is for nonprofit educational purposes; 
Cases and Materials

\section{Statutory and other Supplemental Materials}

(2) the nature of the copyrighted work;

(3) the amount and substantiality of the portion used in relation to the copyrighted work as a whole; and

(4) the effect of the use upon the potential market for or value of the copyrighted work.

The fact that a work is unpublished shall not itself bar a finding of fair use if such finding is made upon consideration of all the above factors.

\section{U.S.C. $\$ 301$}

\section{$\S 301$. Preemption with respect to other laws}

(a) On and after January 1, 1978, all legal or equitable rights that are equivalent to any of the exclusive rights within the general scope of copyright as specified by section 106 in works of authorship that are fixed in a tangible medium of expression and come within the subject matter of copyright as specified by sections 102 and 103, whether created before or after that date and whether published or unpublished, are governed exclusively by this title. Thereafter, no person is entitled to any such right or equivalent right in any such work under the common law or statutes of any State.

(d) Nothing in this title annuls or limits any rights or remedies under the common law or statutes of any State with respect to--

(1) subject matter that does not come within the subject matter of copyright as specified by sections 102 and 103, including works of authorship not fixed in any tangible medium of expression; or

(2) any cause of action arising from undertakings commenced before January 1, 1978;

(3) activities violating legal or equitable rights that are not equivalent to any of the exclusive rights within the general scope of copyright as specified by section 106; or

(4) State and local landmarks, historic preservation, zoning, or building codes, relating to architectural works protected under section 102(a)(8).

(c) With respect to sound recordings fixed before February 15, 1972, any rights or remedies under the common law or statutes of any State shall not be annulled or limited by this title until February 15, 2067. The preemptive provisions of subsection (a) shall apply to any such rights and remedies pertaining to any cause of action arising from undertakings commenced on and after February 15, 2067. Notwithstanding the provisions of section 303, no sound recording fixed before February 15, 1972, shall be subject to copyright under this title before, on, or after February 15, 2067.

(d) Nothing in this title annuls or limits any rights or remedies under any other Federal statute.

(e) The scope of Federal preemption under this section is not affected by the adherence of the United States to the Berne Convention or the satisfaction of obligations of the United States thereunder.

(f)(1) On or after the effective date set forth in section 610(a) of the Visual Artists Rights Act of 1990, all legal or equitable rights that are equivalent to any of the rights conferred by section $106 \mathrm{~A}$ with respect to works of visual art to which the rights conferred by section 106A apply are governed exclusively by section 106A and section 113(d) and the provisions of this title relating to such sections. Thereafter, no person is entitled to any such right or equivalent right in any work of visual art under the common law or statutes of any State. 
(2) Nothing in paragraph (1) annuls or limits any rights or remedies under the common law or statutes of any State with respect to-

(A) any cause of action from undertakings commenced before the effective date set forth in section 610(a) of the Visual Artists Rights Act of 1990;

(B) activities violating legal or equitable rights that are not equivalent to any of the rights conferred by section 106A with respect to works of visual art; or

(C) activities violating legal or equitable rights which extend beyond the life of the author.

17 U.S.C. $\$ 302$

\section{$\S 302$. Duration of copyright: Works created on or after January 1, 1978}

(a) In General.--Copyright in a work created on or after January 1, 1978, subsists from its creation and, except as provided by the following subsections, endures for a term consisting of the life of the author and 70 years after the author's death.

(b) Joint Works.--In the case of a joint work prepared by two or more authors who did not work for hire, the copyright endures for a term consisting of the life of the last surviving author and 70 years after such last surviving author's death.

(c) Anonymous Works, Pseudonymous Works, and Works Made for Hire.--In the case of an anonymous work, a pseudonymous work, or a work made for hire, the copyright endures for a term of 95 years from the year of its first publication, or a term of 120 years from the year of its creation, whichever expires first. If, before the end of such term, the identity of one or more of the authors of an anonymous or pseudonymous work is revealed in the records of a registration made for that work under subsections (a) or (d) of section 408, or in the records provided by this subsection, the copyright in the work endures for the term specified by subsection (a) or (b), based on the life of the author or authors whose identity has been revealed. Any person having an interest in the copyright in an anonymous or pseudonymous work may at any time record, in records to be maintained by the Copyright Office for that purpose, a statement identifying one or more authors of the work; the statement shall also identify the person filing it, the nature of that person's interest, the source of the information recorded, and the particular work affected, and shall comply in form and content with requirements that the Register of Copyrights shall prescribe by regulation.

(d) Records Relating to Death of Authors.--Any person having an interest in a copyright may at any time record in the Copyright Office a statement of the date of death of the author of the copyrighted work, or a statement that the author is still living on a particular date. The statement shall identify the person filing it, the nature of that person's interest, and the source of the information recorded, and shall comply in form and content with requirements that the Register of Copyrights shall prescribe by regulation. The Register shall maintain current records of information relating to the death of authors of copyrighted works, based on such recorded statements and, to the extent the Register considers practicable, on data contained in any of the records of the Copyright Office or in other reference sources.

(e) Presumption as to Author's Death.--After a period of 95 years from the year of first publication of a work, or a period of 120 years from the year of its creation, whichever expires first, any person who obtains from the Copyright Office a certified report that the 
Cases and Materials

\section{Statutory and other Supplemental Materials}

records provided by subsection (d) disclose nothing to indicate that the author of the work is living, or died less than 70 years before, is entitled to the benefit of a presumption that the author has been dead for at least 70 years. Reliance in good faith upon this presumption shall be a complete defense to any action for infringement under this title.

\section{U.S.C. $\$ 502$}

\section{$\S 502$. Remedies for infringement: Injunctions}

(a) Any court having jurisdiction of a civil action arising under this title may, subject to the provisions of section 1498 of title 28, grant temporary and final injunctions on such terms as it may deem reasonable to prevent or restrain infringement of a copyright.

(b) Any such injunction may be served anywhere in the United States on the person enjoined; it shall be operative throughout the United States and shall be enforceable, by proceedings in contempt or otherwise, by any United States court having jurisdiction of that person. The clerk of the court granting the injunction shall, when requested by any other court in which enforcement of the injunction is sought, transmit promptly to the other court a certified copy of all the papers in the case on file in such clerk's office.

\section{U.S.C.\$502}

\section{$\S 504$. Remedies for infringement: Damages and profits}

(a) In General.--Except as otherwise provided by this title, an infringer of copyright is liable for either--

(1) the copyright owner's actual damages and any additional profits of the infringer, as provided by subsection (b); or

(2) statutory damages, as provided by subsection (c).

(b) Actual Damages and Profits.--The copyright owner is entitled to recover the actual damages suffered by him or her as a result of the infringement, and any profits of the infringer that are attributable to the infringement and are not taken into account in computing the actual damages. In establishing the infringer's profits, the copyright owner is required to present proof only of the infringer's gross revenue, and the infringer is required to prove his or her deductible expenses and the elements of profit attributable to factors other than the copyrighted work.

(c) Statutory Damages.--

(1) Except as provided by clause (2) of this subsection, the copyright owner may elect, at any time before final judgment is rendered, to recover, instead of actual damages and profits, an award of statutory damages for all infringements involved in the action, with respect to any one work, for which any one infringer is liable individually, or for which any two or more infringers are liable jointly and severally, in a sum of not less than $\$ 750$ or more than $\$ 30,000$ as the court considers just. For the purposes of this subsection, all the parts of a compilation or derivative work constitute one work. 
Cases and Materials

\section{Statutory and other Supplemental Materials}

(2) In a case where the copyright owner sustains the burden of proving, and the court finds, that infringement was committed willfully, the court in its discretion may increase the award of statutory damages to a sum of not more than $\$ 150,000$. In a case where the infringer sustains the burden of proving, and the court finds, that such infringer was not aware and had no reason to believe that his or her acts constituted an infringement of copyright, the court in its discretion may reduce the award of statutory damages to a sum of not less than $\$ 200$. The court shall remit statutory damages in any case where an infringer believed and had reasonable grounds for believing that his or her use of the copyrighted work was a fair use under section 107, if the infringer was: (i) an employee or agent of a nonprofit educational institution, library, or archives acting within the scope of his or her employment who, or such institution, library, or archives itself, which infringed by reproducing the work in copies or phonorecords; or (ii) a public broadcasting entity which or a person who, as a regular part of the nonprofit activities of a public broadcasting entity (as defined in section 118(f)) infringed by performing a published nondramatic literary work or by reproducing a transmission program embodying a performance of such a work.

(3) (A) In a case of infringement, it shall be a rebuttable presumption that the infringement was committed willfully for purposes of determining relief if the violator, or a person acting in concert with the violator, knowingly provided or knowingly caused to be provided materially false contact information to a domain name registrar, domain name registry, or other domain name registration authority in registering, maintaining, or renewing a domain name used in connection with the infringement.

(B) Nothing in this paragraph limits what may be considered willful infringement under this subsection.

(C) For purposes of this paragraph, the term "domain name" has the meaning given that term in section 45 of the Act entitled "An Act to provide for the registration and protection of trademarks used in commerce, to carry out the provisions of certain international conventions, and for other purposes" approved July 5, 1946 (commonly referred to as the "Trademark Act of 1946"; 15 U.S.C. 1127).

(d) Additional damages in certain cases.--In any case in which the court finds that a defendant proprietor of an establishment who claims as a defense that its activities were exempt under section 110(5) did not have reasonable grounds to believe that its use of a copyrighted work was exempt under such section, the plaintiff shall be entitled to, in addition to any award of damages under this section, an additional award of two times the amount of the license fee that the proprietor of the establishment concerned should have paid the plaintiff for such use during the preceding period of up to 3 years. 
Cases and Materials

Statutory and other Supplemental Materials

\section{Digital Millennium Copyright Act \\ (DMCA)}

\section{U.S.C. $\$ 1201$ \\ $\$ 1201$. Circumvention of copyright protection systems}

(a) Violations regarding circumvention of technological measures.-

(1)(A) No person shall circumvent a technological measure that effectively controls access to a work protected under this title. The prohibition contained in the preceding sentence shall take effect at the end of the 2-year period beginning on the date of the enactment of this chapter.

(B) The prohibition contained in subparagraph (A) shall not apply to persons who are users of a copyrighted work which is in a particular class of works, if such persons are, or are likely to be in the succeeding 3-year period, adversely affected by virtue of such prohibition in their ability to make noninfringing uses of that particular class of works under this title, as determined under subparagraph $(\mathrm{C})$.

(C) During the 2-year period described in subparagraph (A), and during each succeeding 3-year period, the Librarian of Congress, upon the recommendation of the Register of Copyrights, who shall consult with the Assistant Secretary for Communications and Information of the Department of Commerce and report and comment on his or her views in making such recommendation, shall make the determination in a rulemaking proceeding for purposes of subparagraph (B) of whether persons who are users of a copyrighted work are, or are likely to be in the succeeding 3-year period, adversely affected by the prohibition under subparagraph (A) in their ability to make noninfringing uses under this title of a particular class of copyrighted works. In conducting such rulemaking, the Librarian shall examine-

(i) the availability for use of copyrighted works;

(ii) the availability for use of works for nonprofit archival, preservation, and educational purposes;

(iii) the impact that the prohibition on the circumvention of technological measures applied to copyrighted works has on criticism, comment, news reporting, teaching, scholarship, or research;

(iv) the effect of circumvention of technological measures on the market for or value of copyrighted works; and

(v) such other factors as the Librarian considers appropriate.

(D) The Librarian shall publish any class of copyrighted works for which the Librarian has determined, pursuant to the rulemaking conducted under subparagraph $(\mathrm{C})$, that noninfringing uses by persons who are users of a copyrighted work are, or are likely to be, adversely affected, and the prohibition contained in subparagraph (A) shall not apply to such users with respect to such class of works for the ensuing 3-year period.

(E) Neither the exception under subparagraph (B) from the applicability of the prohibition contained in subparagraph (A), nor any determination made in a rulemaking conducted under subparagraph $(\mathrm{C})$, may be used as a defense in any action to enforce any provision of this title other than this paragraph. 
(2) No person shall manufacture, import, offer to the public, provide, or otherwise traffic in any technology, product, service, device, component, or part thereof, that-

(A) is primarily designed or produced for the purpose of circumventing a technological measure that effectively controls access to a work protected under this title;

(B) has only limited commercially significant purpose or use other than to circumvent a technological measure that effectively controls access to a work protected under this title; or

(C) is marketed by that person or another acting in concert with that person with that

person's knowledge for use in circumventing a technological measure that effectively controls access to a work protected under this title.

(3) As used in this subsection-

(A) to "circumvent a technological measure" means to descramble a scrambled work, to decrypt an encrypted work, or otherwise to avoid, bypass, remove, deactivate, or impair a technological measure, without the authority of the copyright owner; and

(B) a technological measure "effectively controls access to a work" if the measure, in the ordinary course of its operation, requires the application of information, or a process or a treatment, with the authority of the copyright owner, to gain access to the work.

(b) Additional violations.-

(1) No person shall manufacture, import, offer to the public, provide, or otherwise traffic in any technology, product, service, device, component, or part thereof, that-

(A) is primarily designed or produced for the purpose of circumventing protection afforded by a technological measure that effectively protects a right of a copyright owner under this title in a work or a portion thereof;

(B) has only limited commercially significant purpose or use other than to circumvent protection afforded by a technological measure that effectively protects a right of a copyright owner under this title in a work or a portion thereof; or

(C) is marketed by that person or another acting in concert with that person with that person's knowledge for use in circumventing protection afforded by a technological measure that effectively protects a right of a copyright owner under this title in a work or a portion thereof.

(2) As used in this subsection-

(A) to "circumvent protection afforded by a technological measure" means avoiding, bypassing, removing, deactivating, or otherwise impairing a technological measure; and

(B) a technological measure "effectively protects a right of a copyright owner under this title" if the measure, in the ordinary course of its operation, prevents, restricts, or otherwise limits the exercise of a right of a copyright owner under this title.

(c) Other rights, etc., not affected.-

(1) Nothing in this section shall affect rights, remedies, limitations, or defenses to copyright infringement, including fair use, under this title.

(2) Nothing in this section shall enlarge or diminish vicarious or contributory liability for copyright infringement in connection with any technology, product, service, device, component, or part thereof.

(3) Nothing in this section shall require that the design of, or design and selection of parts and components for, a consumer electronics, telecommunications, or computing product 
provide for a response to any particular technological measure, so long as such part or component, or the product in which such part or component is integrated, does not otherwise fall within the prohibitions of subsection (a)(2) or (b)(1).

(4) Nothing in this section shall enlarge or diminish any rights of free speech or the press for activities using consumer electronics, telecommunications, or computing products.

(d) Exemption for nonprofit libraries, archives, and educational institutions.-

(1) A nonprofit library, archives, or educational institution which gains access to a commercially exploited copyrighted work solely in order to make a good faith determination of whether to acquire a copy of that work for the sole purpose of engaging in conduct permitted under this title shall not be in violation of subsection (a)(1)(A). A copy of a work to which access has been gained under this paragraph-

(A) may not be retained longer than necessary to make such good faith determination; and

(B) may not be used for any other purpose.

(2) The exemption made available under paragraph (1) shall only apply with respect to a work when an identical copy of that work is not reasonably available in another form.

(3) A nonprofit library, archives, or educational institution that willfully for the purpose of commercial advantage or financial gain violates paragraph (1) -

(A) shall, for the first offense, be subject to the civil remedies under section 1203; and

(B) shall, for repeated or subsequent offenses, in addition to the civil remedies under section 1203, forfeit the exemption provided under paragraph (1).

(4) This subsection may not be used as a defense to a claim under subsection (a)(2) or (b), nor may this subsection permit a nonprofit library, archives, or educational institution to manufacture, import, offer to the public, provide, or otherwise traffic in any technology, product, service, component, or part thereof, which circumvents a technological measure.

(5) In order for a library or archives to qualify for the exemption under this subsection, the collections of that library or archives shall be-

(A) open to the public; or

(B) available not only to researchers affiliated with the library or archives or with the institution of which it is a part, but also to other persons doing research in a specialized field.

(e) Law enforcement, intelligence, and other government activities.--This section does not prohibit any lawfully authorized investigative, protective, information security, or intelligence activity of an officer, agent, or employee of the United States, a State, or a political subdivision of a State, or a person acting pursuant to a contract with the United States, a State, or a political subdivision of a State. For purposes of this subsection, the term "information security" means activities carried out in order to identify and address the vulnerabilities of a government computer, computer system, or computer network.

\section{(f) Reverse engineering.- -}

(1) Notwithstanding the provisions of subsection (a)(1)(A), a person who has lawfully obtained the right to use a copy of a computer program may circumvent a technological measure that effectively controls access to a particular portion of that program for the sole purpose of identifying and analyzing those elements of the program that are 
necessary to achieve interoperability of an independently created computer program with other programs, and that have not previously been readily available to the person engaging in the circumvention, to the extent any such acts of identification and analysis do not constitute infringement under this title.

(2) Notwithstanding the provisions of subsections (a)(2) and (b), a person may develop and employ technological means to circumvent a technological measure, or to circumvent protection afforded by a technological measure, in order to enable the identification and analysis under paragraph (1), or for the purpose of enabling interoperability of an independently created computer program with other programs, if such means are necessary to achieve such interoperability, to the extent that doing so does not constitute infringement under this title.

(3) The information acquired through the acts permitted under paragraph (1), and the means permitted under paragraph (2), may be made available to others if the person referred to in paragraph (1) or (2), as the case may be, provides such information or means solely for the purpose of enabling interoperability of an independently created computer program with other programs, and to the extent that doing so does not constitute infringement under this title or violate applicable law other than this section.

(4) For purposes of this subsection, the term "interoperability" means the ability of computer programs to exchange information, and of such programs mutually to use the information which has been exchanged.

(g) Encryption research.-

(1) Definitions.--For purposes of this subsection-

(A) the term "encryption research" means activities necessary to identify and analyze flaws and vulnerabilities of encryption technologies applied to copyrighted works, if these activities are conducted to advance the state of knowledge in the field of encryption technology or to assist in the development of encryption products; and

(B) the term "encryption technology" means the scrambling and descrambling of information using mathematical formulas or algorithms.

(2) Permissible acts of encryption research.--Notwithstanding the provisions of subsection (a)(1)(A), it is not a violation of that subsection for a person to circumvent a technological measure as applied to a copy, phonorecord, performance, or display of a published work in the course of an act of good faith encryption research if-

(A) the person lawfully obtained the encrypted copy, phonorecord, performance, or display of the published work;

(B) such act is necessary to conduct such encryption research;

(C) the person made a good faith effort to obtain authorization before the circumvention; and

(D) such act does not constitute infringement under this title or a violation of applicable law other than this section, including section 1030 of title 18 and those provisions of title 18 amended by the Computer Fraud and Abuse Act of 1986.

(3) Factors in determining exemption.--In determining whether a person qualifies for the exemption under paragraph (2), the factors to be considered shall include-

(A) whether the information derived from the encryption research was disseminated, and if so, whether it was disseminated in a manner reasonably calculated to advance the 


\section{Statutory and other Supplemental Materials}

state of knowledge or development of encryption technology, versus whether it was disseminated in a manner that facilitates infringement under this title or a violation of applicable law other than this section [17 U.S.C.A. $§ 1$ et seq.], including a violation of privacy or breach of security;

(B) whether the person is engaged in a legitimate course of study, is employed, or is appropriately trained or experienced, in the field of encryption technology; and

(C) whether the person provides the copyright owner of the work to which the technological measure is applied with notice of the findings and documentation of the research, and the time when such notice is provided.

(4) Use of technological means for research activities.--Notwithstanding the provisions of subsection (a)(2), it is not a violation of that subsection for a person to-

(A) develop and employ technological means to circumvent a technological measure for the sole purpose of that person performing the acts of good faith encryption research described in paragraph (2); and

(B) provide the technological means to another person with whom he or she is working collaboratively for the purpose of conducting the acts of good faith encryption research described in paragraph (2) or for the purpose of having that other person verify his or her acts of good faith encryption research described in paragraph (2).

(5) Report to Congress.--Not later than 1 year after the date of the enactment of this chapter [17 U.S.C. 1201 et seq.], the Register of Copyrights and the Assistant Secretary for Communications and Information of the Department of Commerce shall jointly report to the Congress on the effect this subsection has had on-

(A) encryption research and the development of encryption technology;

(B) the adequacy and effectiveness of technological measures designed to protect copyrighted works; and

(C) protection of copyright owners against the unauthorized access to their encrypted copyrighted works.

The report shall include legislative recommendations, if any.

(h) Exceptions regarding minors.--In applying subsection (a) to a component or part, the court may consider the necessity for its intended and actual incorporation in a technology, product, service, or device, which-

(1) does not itself violate the provisions of this title; and

(2) has the sole purpose to prevent the access of minors to material on the Internet.

(i) Protection of personally identifying information.-

(1) Circumvention permitted.--Notwithstanding the provisions of subsection

(a)(1)(A), it is not a violation of that subsection for a person to circumvent a technological measure that effectively controls access to a work protected under this title, if-

(A) the technological measure, or the work it protects, contains the capability of collecting or disseminating personally identifying information reflecting the online activities of a natural person who seeks to gain access to the work protected;

(B) in the normal course of its operation, the technological measure, or the work it protects, collects or disseminates personally identifying information about the 
person who seeks to gain access to the work protected, without providing conspicuous notice of such collection or dissemination to such person, and without providing such person with the capability to prevent or restrict such collection or dissemination;

(C) the act of circumvention has the sole effect of identifying and disabling the capability described in subparagraph (A), and has no other effect on the ability of any person to gain access to any work; and

(D) the act of circumvention is carried out solely for the purpose of preventing the collection or dissemination of personally identifying information about a natural person who seeks to gain access to the work protected, and is not in violation of any other law.

(2) Inapplicability to certain technological measures.--This subsection does not apply to a technological measure, or a work it protects, that does not collect or disseminate personally identifying information and that is disclosed to a user as not having or using such capability.

\section{(j) Security testing.--}

(1) Definition.--For purposes of this subsection, the term "security testing" means accessing a computer, computer system, or computer network, solely for the purpose of good faith testing, investigating, or correcting, a security flaw or vulnerability, with the authorization of the owner or operator of such computer, computer system, or computer network.

(2) Permissible acts of security testing.--Notwithstanding the provisions of subsection (a)(1)(A), it is not a violation of that subsection for a person to engage in an act of security testing, if such act does not constitute infringement under this title or a violation of applicable law other than this section, including section 1030 of title 18 and those provisions of title 18 amended by the Computer Fraud and Abuse Act of 1986.

(3) Factors in determining exemption.--In determining whether a person qualifies for the exemption under paragraph (2), the factors to be considered shall include-

(A) whether the information derived from the security testing was used solely to promote the security of the owner or operator of such computer, computer system or computer network, or shared directly with the developer of such computer, computer system, or computer network; and

(B) whether the information derived from the security testing was used or maintained in a manner that does not facilitate infringement under this title or a violation of applicable law other than this section, including a violation of privacy or breach of security.

(4) Use of technological means for security testing.--Notwithstanding the provisions of subsection (a)(2), it is not a violation of that subsection for a person to develop, produce, distribute or employ technological means for the sole purpose of performing the acts of security testing described in subsection (2), ${ }^{1}$ provided such technological means does not

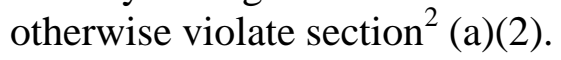

(k) Certain analog devices and certain technological measures.(1) Certain analog devices.- 
Cases and Materials

Statutory and other Supplemental Materials

(A) Effective 18 months after the date of the enactment of this chapter, no person shall manufacture, import, offer to the public, provide or otherwise traffic in any-

(i) VHS format analog video cassette recorder unless such recorder conforms to the automatic gain control copy control technology;

(ii) $8 \mathrm{~mm}$ format analog video cassette camcorder unless such camcorder conforms to the automatic gain control technology;

(iii) Beta format analog video cassette recorder, unless such recorder conforms to the automatic gain control copy control technology, except that this requirement shall not apply until there are 1,000 Beta format analog video cassette recorders sold in the United States in any one calendar year after the date of the enactment of this chapter;

(iv) $8 \mathrm{~mm}$ format analog video cassette recorder that is not an analog video cassette camcorder, unless such recorder conforms to the automatic gain control copy control technology, except that this requirement shall not apply until there are 20,000 such recorders sold in the United States in any one calendar year after the date of the enactment of this chapter; or

(v) analog video cassette recorder that records using an NTSC format video input and that is not otherwise covered under clauses (i) through (iv), unless such device conforms to the automatic gain control copy control technology.

(B) Effective on the date of the enactment of this chapter, no person shall manufacture, import, offer to the public, provide or otherwise traffic in(i) any VHS format analog video cassette recorder or any $8 \mathrm{~mm}$ format analog video cassette recorder if the design of the model of such recorder has been modified after such date of enactment so that a model of recorder that previously conformed to the automatic gain control copy control technology no longer conforms to such technology; or

(ii) any VHS format analog video cassette recorder, or any $8 \mathrm{~mm}$ format analog video cassette recorder that is not an $8 \mathrm{~mm}$ analog video cassette camcorder, if the design of the model of such recorder has been modified after such date of enactment so that a model of recorder that previously conformed to the four-line colorstripe copy control technology no longer conforms to such technology.

Manufacturers that have not previously manufactured or sold a VHS format analog video cassette recorder, or an $8 \mathrm{~mm}$ format analog cassette recorder, shall be required to conform to the four-line colorstripe copy control technology in the initial model of any such recorder manufactured after the date of the enactment of this chapter, and thereafter to continue conforming to the four-line colorstripe copy control technology. For purposes of this subparagraph, an analog video cassette recorder "conforms to" the four-line colorstripe copy control technology if it records a signal that, when played back by the playback function of that recorder in the normal viewing mode, exhibits, on a reference display 
Cases and Materials

Statutory and other Supplemental Materials

device, a display containing distracting visible lines through portions of the viewable picture.

(2) Certain encoding restrictions.--No person shall apply the automatic gain control copy control technology or colorstripe copy control technology to prevent or limit consumer copying except such copying-

(A) of a single transmission, or specified group of transmissions, of live events or of audiovisual works for which a member of the public has exercised choice in selecting the transmissions, including the content of the transmissions or the time of receipt of such transmissions, or both, and as to which such member is charged a separate fee for each such transmission or specified group of transmissions;

(B) from a copy of a transmission of a live event or an audiovisual work if such transmission is provided by a channel or service where payment is made by a member of the public for such channel or service in the form of a subscription fee that entitles the member of the public to receive all of the programming contained in such channel or service;

(C) from a physical medium containing one or more prerecorded audiovisual works; or

(D) from a copy of a transmission described in subparagraph (A) or from a copy made from a physical medium described in subparagraph (C).

In the event that a transmission meets both the conditions set forth in subparagraph (A) and those set forth in subparagraph (B), the transmission shall be treated as a transmission described in subparagraph (A).

(3) Inapplicability.--This subsection shall not-

(A) require any analog video cassette camcorder to conform to the automatic gain control copy control technology with respect to any video signal received through a camera lens;

(B) apply to the manufacture, importation, offer for sale, provision of, or other trafficking in, any professional analog video cassette recorder; or

(C) apply to the offer for sale or provision of, or other trafficking in, any previously owned analog video cassette recorder, if such recorder was legally manufactured and sold when new and not subsequently modified in violation of paragraph $(1)(\mathrm{B})$.

(4) Definitions.--For purposes of this subsection:

(A) An "analog video cassette recorder" means a device that records, or a device that includes a function that records, on electromagnetic tape in an analog format the electronic impulses produced by the video and audio portions of a television program, motion picture, or other form of audiovisual work.

(B) An "analog video cassette camcorder" means an analog video cassette recorder that contains a recording function that operates through a camera lens and through a video input that may be connected with a television or other video playback device. 


\section{Cases and Materials}

\section{Statutory and other Supplemental Materials}

(C) An analog video cassette recorder "conforms" to the automatic gain control copy control technology if it-

(i) detects one or more of the elements of such technology and does not record the motion picture or transmission protected by such technology; or (ii) records a signal that, when played back, exhibits a meaningfully distorted or degraded display.

(D) The term "professional analog video cassette recorder" means an analog video cassette recorder that is designed, manufactured, marketed, and intended for use by a person who regularly employs such a device for a lawful business or industrial use, including making, performing, displaying, distributing, or transmitting copies of motion pictures on a commercial scale.

(E) The terms "VHS format", "8mm format", "Beta format", "automatic gain control copy control technology", "colorstripe copy control technology", "four-line version of the colorstripe copy control technology", and "NTSC" have the meanings that are commonly understood in the consumer electronics and motion picture industries as of the date of the enactment of this chapter.

(5) Violations.--Any violation of paragraph (1) of this subsection shall be treated as a violation of subsection (b)(1) of this section. Any violation of paragraph (2) of this subsection shall be deemed an "act of circumvention" for the purposes of section 1203(c)(3)(A) of this chapter. 


\section{INNOVATION AND COMPETITION POLICY CASES AND MATERIALS \\ TABLE OF CONTENTS (2d)}

\section{Chapter 1. Competition Policy and the Scope of Intellectual Property Protection}

Wright Co. v. Herring-Curtiss Co., 204 F. 597 (W.D.N.Y 1913)

Notes and Questions

Festo Corp. v. Shoketsu Kinzoku Kogyo Kabushiki Co., 234 F.3d 558 (Fed. Cir. 2000), rev'd, 535 U.S. 722 (2002)

Notes and Questions

Traffix Devices, Inc. v. Marketing Displays Inc. 532 U.S. 23 (2001)

Notes and Questions

Note: Design Patents and Interoperability

Note: Competition and the "Trademark Use" Doctrine

\section{Chapter 2. Complementary Products and Processes: The Law of Tying}

Henry v. A. B. Dick Co., 224 U.S. 1 (1912)

Notes and Questions

Note: Variable Proportion Ties: Price Discrimination and Welfare Effects

Motion Picture Patents Co. v. Universal Film Manufacturing Co., 243 U.S. 502 (1917)

Carbice Corp. of America v. American Patents Development Corp., 283 U.S. 27 (1931)

Notes and Questions

International Salt Co. v. United States, 332 U.S. 392 (1947)

Notes and Questions

Siegel v. Chicken Delight, Inc., 448 F.2d 43 (9th Cir. 1971)

Notes and Questions

Queen City Pizza, Inc. v. Domino’s Pizza, Inc., 124 F.3d 430 (3d Cir. 1997)

Notes and Questions

United States v. Loew's, Inc., 371 U.S. 38 (1962)

Notes and Questions

United States v. Microsoft Corp., 253 F.3d 34 (D.C. Cir.) cert. denied, 534 U.S. 952 (2001) 
Cases and Materials

Statutory and other Supplemental Materials

Notes and Questions

Illinois Tool Works, Inc., v. Independent Ink, Inc., 547 U.S. 28 (2006)

Notes and Questions

Brantley v. NBC Universal, Inc., 649 F.3d 1078 (9th Cir. 2011), vacated Oct. 31, 2011

Notes and Questions

Chapter 3: Harm to Competition or Innovation: Remedies

Brunswick Corp. v. Pueblo Bowl-O-Mat, Inc., 429 U.S. 477 (1977)

Notes and Questions

Note: Mergers That Restrain Innovation

Andreas v. Volkswagen of America, Inc., 336 F.3d 789 (8th Cir. 2003)

Notes and Questions

Ty, Inc. v. Public International Ltd., 292 F.3d 512 (7th Cir. 2002)

Notes and Questions

Garretson v. Clark, 111 U.S. 120 (1884)

Notes and Questions

IP Innovation, LLC v. Red Hat, Inc., 705 F.Supp.2d 687 (E.D.Tex. 2010)

Ricoh Co., Ltd. v. Quanta Computer, Inc., 2010 WL 1607908 (W.D.Wis. 2010)

Notes and Questions

\section{Chapter 4: Competition Policy and the Patent System}

Walker Process Equipment, Inc. v. Food Machine and Chemical Corp., 382 U.S. 172 (1965)

Notes and Questions

Dippin' Dots, Inc. v. Mosey, 476 F.3d 1337 (Fed. Cir. 2007)

Notes and Questions

In Re DDAVP Direct Purchaser Antitrust Litigation, 585 F.3d 677 (2nd Cir. 2009)

Notes and Questions

Therasense, Inc. v. Becton, Dickinson and Co., 649 F.3d 1276 (Fed. Cir. 2011)

Notes and Questions

Eon-Net LP v. Flagstar Bancorp, 653 F.3d 1314 (Fed. Cir. 2011)

Notes and Questions

Rambus, Inc. v. Federal Trade Commission, 522 F.3d 456 (D.C.Cir. 2008) 
Notes and Questions

Arkansas Carpenters Health and Welfare Fund v. Bayer AG, 604 F.3d 98 (2d Cir. 2010)

Notes and Questions

Note: Patent vs. Trademark Settlements

\section{Chapter 5: Competition and Innovation in Copyright and the DMCA}

\section{EXCLUSION BY COPYRIGHT}

Assessment Tech. of WI., LLC v. WIREdata, Inc., 350 F.3d 640 (7th Cir. 2003)

Notes and Questions

ProCD, Inc. v. Zeidenberg, 86 F.3d 1447 (7th Cir. 1996)

Notes and Questions

\section{COMPETITION POLICY AND THE DMCA}

Chamberlain Group, Inc. v. Skylink Tech., Inc., 381 F.3d 1178 (Fed. Cir. 2004) Notes and Questions

\section{ANTITRUST AND COPYRIGHT EXCLUSION}

Professional Real Estate Investors, Inc. v. Columbia Pictures 508 U.S. 49 (1993) Notes and Questions

Paddock Publications, Inc. v. Chicago Tribune Co., 103 F.3d 42 (7th Cir. 1996) Notes and Questions

The Authors Guild v. Google, Inc., 770 F.Supp.2d 666 (S.D.N.Y. 2011)

Notes and Questions

\section{Chapter 6: Restraints on Innovation}

Allied Tube \& Conduit Corp. v. Indian Head, Inc., 486 U.S. 492 (1988)

Notes and Questions

Note: Mergers and Restraints on Innovation

Kloth v. Microsoft Corp., 444 F.3d 312 (4th Cir. 2006)

Notes and Questions

\section{Chapter 7: Intellectual Property Misuse}

Lasercomb America, Inc. v. Reynolds, 911 F.2d 970 (4th Cir. 1990)

Notes and Questions 
Cases and Materials

Statutory and other Supplemental Materials

Senza-Gel Corp. v. Seiffhart, 803 F.2d 661 (Fed. Cir. 1986)

Note

Monsanto Co. v. Scruggs, 459 F.3d 1328 (Fed. Cir. 2006)

Notes and Questions

Princo Corp. v. International Trade Commission, 616 F.3d 1318 (Fed. Cir. 2010)

Notes and Questions

Brulotte v. Thys Co., 379 U.S. 29 (1964)

Scheiber v. Dolby Labs., Inc 293 F.3d 1014 (7th Cir. 2002)

Notes and Questions

County Materials Corp. v. Allan Block Corp., 502 F.3d 730 (7th Cir. 2007)

Bayer AG v. Housey Pharmaceuticals, Inc., 228 F.Supp.2d 467 (D. Del. 2002)

Notes and Questions

\section{Chapter 8: Innovation, IP Rights, and Anticompetitive Exclusion}

Continental Paper Bag Company v. Eastern Paper Bag Company, 210 U.S. 405 (1908)

Notes and Questions

Wallace v. IBM Corp., 467 F.3d 1104 (7th Cir. 2006)

Notes and Questions

Image Technical Services, Inc. v. Eastman Kodak Co., 125 F.3d 1195 (9th Cir. 1997), cert. denied, 523 U.S. 1094 (1998)

Notes and Questions

Microsoft Corp. v. Commission of the European Communities (Case T-201/04 European Court of First Instance, Sep. 2007)

Notes and Questions

Note: The United States Antitrust Law of Refusal to Deal

Allied Orthopedic Appliances, Inc. v. Tyco Health Care Group, LP, 592 F.3d 991 (9th Cir. 2010)

Notes and Questions

Talk America, Inc. v. Michigan Bell Telephone Co., 131 S.Ct. 2254 (2011)

Notes and Questions

Note: Net Neutrality

Notes and Questions 


\section{Chapter 9: The Innovation Commons}

Brooks v. Byam, 2 Story 525, 4 F.Cas. 261 (C.C.Mas 1843)

Notes and Questions

E. Bement \& Sons v. National Harrow Co., 186 U.S. 70 (1902)

Notes and Questions

United States v. General Electric Co., 272 U.S. 476 (1926)

Notes and Questions

Stamdard Oil Co. (Indiana) et. al. v. United States, 283 U.S. 163 (1931)

Note: Patent Pools: Blocking Relationships, Price Fixing and Boundary Ambiguity

Automatic Radio Manufacturing Co., v. Hazeltine Research, Inc., 339 U.S. 827 (1950)

Notes and Questions

United States v. Singer Manufacturing Co., 374 U.S. 174 (1963)

Notes and Questions

Nero AG v. MPEG LA, LLC. 2010 WL 4878835 (C.D. Cal. Nov. 24, 2010)

Notes and Questions

Note: Patent Pools: "Non-Essential” Patents, Foreclosure, and Price Discrimination

Broadcast Music, Inc. v. Moor-Law, Inc., 527 F. Supp. 758 (D. Del. 1981)

Notes and Questions

Golden Bridge Technology, Inc. v. Motorola, Inc., 547 F.3d 266 (5th Cir. 2007)

Notes and Questions

Polygram Holding, Inc. v. FTC, 416 F.3d 29 (D.C.Cir. 2005)

Notes and Questions

\section{Chapter 10: Post-Sale and Related Distribution Restraints Involving IP Rights}

Adams v. Burke, 84 U.S. 453 (1873)

Notes and Questions

General Talking Pictures Corp. v. Western Electric Co., Inc., 305 U.S. 124 (1939)

Notes and Questions

United States v. Univis Lens Co., 316 U.S. 241 (1942)

Notes and Questions 


\section{Cases and Materials}

Statutory and other Supplemental Materials

Note: Resale Price Maintenance

Quanta Computer, Inc. v. LG Electronics, Inc., 553 U.S. 617 (2008)

Notes and Questions

Vernor v. Autodesk, Inc., 621 F3d 1102 (9th Cir. 2010)

Notes and Questions 